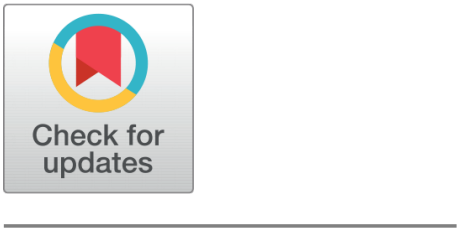

open access

Received: 03.04.2021

Accepted: 28.09.2021

Published: 09.11.2021

\section{Efficacy of Rice Hull Ash against Bacterial Leaf Blight, Xanthomonas oryzae pv. oryzae}

\author{
Yvette D Medrano ${ }^{1}{ }^{*}$, Gerald M Duza ${ }^{1}$, Ricardo B Casauay ${ }^{1}$, Andrea F Dawan ${ }^{1}$, \\ Lyle Gavien L Alcomendras ${ }^{2}$ \\ 1 Faculty, College of Agriculture, Cagayan State University-Piat Campus, Baung Piat Cagayan \\ R02, 3527, Philippines \\ 2 Research Assistant, College of Agriculture, Cagayan State University-Piat Campus, Baung \\ Piat Cagayan R02, 3527, Philippines
}

Citation: Medrano YD, Duza GM, Casauay RB, Dawan AF, Alcomendras LGL (2021) Efficacy of Rice Hull Ash against Bacterial Leaf Blight, Xanthomonas oryzae pv. oryzae. Indian Journal of Science and Technology 14(37): 2880-2887. https://doi.org/ 10.17485/IJST/v14i37.570

* Corresponding author. medranoyvette48@gmail.com Funding: None

Competing Interests: None Copyright: (c) 2021 Medrano et al. This is an open access article distributed under the terms of the Creative Commons Attribution License, which permits unrestricted use, distribution, and reproduction in any medium, provided the original author and source are credited.

Published By Indian Society for Education and Environment (iSee)

ISSN

Print: 0974-6846

Electronic: 0974-5645

\section{Abstract}

Objectives: Silica is not essential nutrients for plant growth; however, it shows that it is beneficial to rice, especially under stress conditions. This study is to test the efficacy of Rice Hull Ash (RHA) as a silicon source to enhance rice resistance against bacterial leaf blight, Xanthomonas oryzae pv. oryzae. Methods: The Complete Randomized Design (CRD) was adopted for the different treatments, replicated four (4) times. CSUT0 (control), CSUT1(30 grams RHA, Basal Application), CSUT2(30 grams RHA, Basal Application; 15 DAT), CSUT3 (30 grams RHA, Basal Application; 15 DAT and 30 DAT), and CSUT4 (30 grams RHA, Basal Application, 15 DAT, 30 DAT; and 40 DAT). The effect of all the treatments is on the severity of infection of the bacteria, plant height and wt.\% of $\mathrm{SiO} 2$ acquired from soil, RHA and test plant. Findings: Rice Hull Ash (RHA) composed of 87.34 wt. \% of SiO2 while soil collected from the Rice Field composed of 68.49 wt.\% of $\mathrm{SiO} 2$, Disease resistance is as high as $60 \%$ when compared with the highest infection rate (T0) to the lowest infection rate (T4). Plant height and resistance produced against BLB infection was observed significantly in CSUT3 (Basal application at 15 and 30 DAT and 30 grams of RHA). Novelty: The study offers an interesting organic alternative that could be used in controlling Bacterial Leaf Blight (BLB).

Keywords: Bacterial Leaf Blight; Rice; Rice hull ash (RHA); Resistance Mechanism; Silica (SiO2)

\section{Introduction}

Rice is considered an ancient domesticated cereal food crop and is arguably the most important staple food for people ${ }^{(1)}$, concentrated production is in Asia as a primary source of food for more than half of the world population ${ }^{(2)}$. In the Philippines, rice is the staple food and the primary source of income of many Filipinos, and the major setback of the country is to sustain rice production. To attain product sustainability, many factors have to be considered, such as soil nutrient requirements and the control of diseases. One of the significant problems of farmers nowadays is the occurrence 
of bacterial blight diseases restricting production, especially in rice not only in the Philippines but also in other countries. Some viable and effective intervention has been established to control this disease, like applying chemical control and improvement of plant resistant, tolerant to the disease. Thus, it is essential to develop effective and viable alternative measures to control BLB infestation ${ }^{(3)}$. Rice husk (RH), as an agricultural waste after harvesting, is rich in silica, containing 90 - $98 \%$ undergoing complete combustion, when compared to other agricultural wastes. Rice Hull Ash (RHA) is also known as boiler fuel, and the ash produced causes severe problems like waste disposal. Wheat, rice, maize, and rice, which belong to the Gramineae family, are primary sources of silica. Mono silicic acid residues in the cells as hydrated deposits, and it will move by evaporation of polymerized silica to force a cellulose silica membrane making the rice hull relatively flaky, brittle, and abrasive. It is chiefly composed of $89 \%-97 \%$ of silica, if undergone incomplete combustion, making it a good source of silicon ${ }^{(4)}$. However, manufacturing pure silica is energy-intensive, which required high furnace temperatures, more than $700^{\circ} \mathrm{C} . \mathrm{O}^{\mathrm{O} o j a h}{ }^{(5)}$ added that rice hull ash contents depend on various crops, geographical location, and fertilizer application. According to ${ }^{(6)}$, silicon is one of the most important trace elements with multifunctional compounds. Still, at the same time, silicon is one of the neglected micro-nutrient elements present in the soil. Given that Si ranked as the second most abundant trace element after oxygen, it hasn't been studied as much as other elements like nitrogen $(\mathrm{N})$ and phosphorus $(\mathrm{P})$. Factors maybe because of its abundance in the area and its undervalued role. The availability of silicon to absorb by plants is affected by the $\mathrm{pH}$ and solubility of the silicon. The weathering process is also one of the main factors because the availability of silicon will be depleted as the weathering process increases. This phenomenon usually occurs in the tropical region ${ }^{(7)}$. In-plant resistance to pathogens, plants release a different chemical compound that interferes with the activities of the pathogen. This chemical compound may act directly as toxic or lytic to the pathogen. Plant cells contain several enzymes like chitinases and glucanases, that cause breakdown of a pathogen cell wall component. A type of active chemical defense of plants together with hypersensitive responses (HR) is the Systematic Acquired Resistance (SAR), pathogenesis-related (PR) proteins, and phytoalexins also play important role in defending the plants from pathogen invasion. The pattern of pathogenesis in a most host-parasite relationship, plant exhibit their defense mechanism as soon as the infection occurs, the moment the pathogen contacts with the host plants, it regulates its defense in the formation of chemical and physical barriers; this process acquired due to the hereditary characters of many plants ${ }^{(8)}$. Using a lot of mitigation or intervention has been employed to control bacterial leaf blight, such as synthetic bactericidal and biological control. However, though some are sufficient and some are detrimental, they are still not enough to sustain production for the country's growing population. Inducing the plant's chemical defense system is also one of the control methods known to exhibit significant effects. Silicon is an ideal candidate to generate the chemical defense system of rice because it acts as an enhancer of resistance and mitigates environmental stresses ${ }^{(9)}$ and mechanically impedes the penetration of pathogens, and prevents the infection process. Most farmers in the Philippines usually use synthetic pesticides to control pests and diseases. It is advantageous and convenient; hence, it became the most popular control strategy. However, synthetic pesticides, especially those non-biodegradable, may harm not only the target pest organisms. The continues application of synthetic pesticide have posed a significant challenge to the target pest organism causing to disperse to a new environment, or they will adopt new conditions ${ }^{(10)}$. Moreover, it also negatively affects humans, animals, and the environment. With this phenomenon, scientists are continuously finding and developing other alternative control to pests and diseases, which are economical, effective, and eco-friendly.

This study conducted to test the possibilities of rice debris as a silicon source to develop resistance for the rice to control Bacterial Leaf Blight disease. Given that Silicon is still not considered an essential element, literature shows that Si has to have positive/beneficial effects on the control of some diseases, make the plants more resistant, induced plant defense, and help to regulate the uptake of other plants nutrient ${ }^{(11)}$. This study aims to (1) determine the wt $\%$ of silicon present in the soil gained in the field, rice hull ash, and test plant, (2) evaluate the different level of rice hull ash, and assess which among these levels will develop a defense mechanism against bacterial leaf blight (BLB).

\section{Materials and Methods}

\subsection{Study area}

The experiment carried out at the Experimental Station of Agricultural College of Cagayan State University-Piat Campus, the analysis of silica content in rice ash using the Gravimetric analysis of Silicon and for the soil through Bauxite Package by Lithium Borate Fusion/XRF was carried out at Intertek Laboratory on West Service Road Cupang, Muntinlupa City, Philippines, from July 2017 to February 2018. 


\subsection{Sample Preparations, Collection of Soil and Rice Hull}

Collection of soil samples was done in one (1) hectare Ricefield of the CSU integrated farm. Ten sampling points were marked within the area. Each sampling point dug in a depth of fifteen (15) centimeters with a length of twenty-five (25) centimeters and a width of twenty-five (25) centimeters. One (1) kilogram sample was obtained after mixed in a container. The rice hull was acquired at Maguilling, Piat, Cagayan, and subjected to complete combustion through conventional burning of rice hull. After complete combustion, two hundred fifty (250) grams of rice hull ash were taken. All representative samples were brought to Intertek Laboratory at West Service Rd., Cupang, Muntinlupa City, for silica content analysis.

\subsection{Collection of diseased leaves}

Rice leaves showing symptoms of bacterial leaf blight collected from various rice fields at Baung, Piat Cagayan. Identification of the developed rice disease was at the maturity stage of the plants; random methods were used in collecting the infected samples. The leaves with symptoms of Bacterial leaf blight are carefully detached and put in a storage container, and labeled carefully, which includes the location of the farm and date sampling, samples obtained taken at the laboratory, and kept in the refrigerator before the conduct of the study.

\subsection{Preparation of Seedlings}

Susceptible rice variety is used as planting material, gained from the Municipal Agricultural Office-Municipality of Piat, Cagayan. The seeds soaked in water for twenty- four (24) hours and sowed on a seedbed for germination, and placed inside the greenhouse to prevent biotic and abiotic stresses damages and, after twenty-one (21) days, transplanting of two (2) seedlings employed in each experimental container pot.

\subsection{Isolation and Inoculation of Xanthomonas oryzae pv oryzae}

To remove the excess debris attached to the leaves, washing with running water was employed. The infected leaves are hung on a stick or thin wire that runs across the beaker so that the bacterial exudate is immersed in distilled water, the bio-safety hood prepared for isolation. The streak plate method was used for isolating the Xanthomonas oryzae pv. oryzae. Pure cultures of $X$. oryzae pv. oryzae transferred from the Petri plates to the prepared sterile agar slants. The pure culture at the sterile agar was incubated at room temperature for 24 hours before use. Using a five-week-old susceptible rice variety, the clipping method implements in the inoculation of the rice leaves by cutting the leaf tip to $3-4 \mathrm{~cm}$. The experimental pot with rice plants was grown at $25-32^{\circ} \mathrm{C}$, with relative humidity ranging from $90 \%-95 \%$.

\subsection{Experimental Design and Treatments}

Table 1. The treatments are shown in the table arranged in a Completely Randomized Design (CRD) with four replications

\begin{tabular}{ll}
\hline Treatment No. & Description \\
\hline T0 & Control (No RHA applied) \\
T1 & Basal application (30g of RHA) \\
T2 & Basal \& 15 DAT (30g of RHA per \\
& Application) \\
T3 & Basal, 15 DAT \& 30 DAT (30g of \\
& RHA per Application) \\
T4 & Basal, 15 DAT, 30 DAT \& 40 DAT \\
& (30g of RHA per Application) \\
\hline
\end{tabular}

\subsection{Disease Evaluation for Xanthomonas oryzae pv oryzae}

Two (2) days after inoculation (DAI), the severity of bacterial blight infection and disease index evaluated using for Rice Standard Evaluation System (SES) issued by ${ }^{(10)}$, as reflected in Table ??. The percentage estimated through the Standard area diagram. 
Table 2. Greenhouse test, severity: \% leaf area diseased

\begin{tabular}{ll}
\hline Scale & Description \\
\hline 1 & $\begin{array}{l}\text { No diseases } \\
\text { observed }\end{array}$ \\
2 & Less than $1 \%^{*}$ \\
3 & $1-3 \%^{*}$ \\
4 & $4-5 \%^{*}$ \\
5 & $11-15 \%^{*}$ \\
6 & $16-25 \%^{*}$ \\
7 & $26-50 \%^{*}$ \\
8 & $51-75 \%^{*}$ \\
9 & $76-100 \%^{*}$ \\
\hline
\end{tabular}

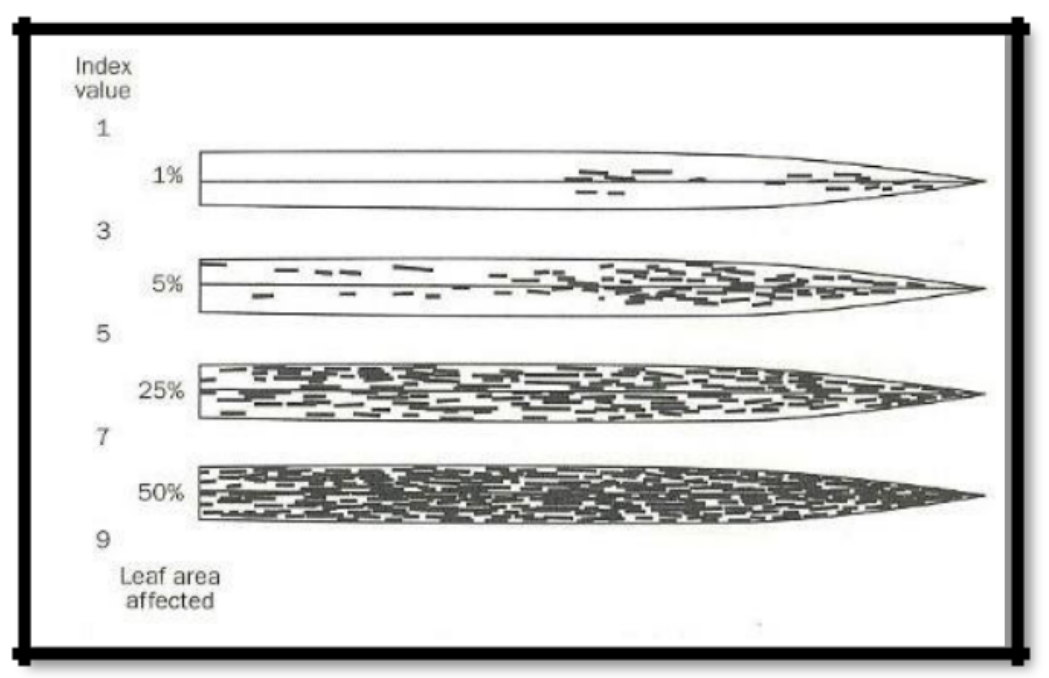

Fig 1. The index value and the corresponding levels of severity for a leaf streak disease ${ }^{(10)}$.

Table 3. Diseaseindex

\begin{tabular}{lll}
\hline \multicolumn{2}{l}{$\begin{array}{l}\text { Disease } \\
\text { Index }\end{array}$} & Reaction \\
\hline 0 & $0-3$ & Resistant/Tolerant \\
4 & $4-6$ & Moderate \\
7 & $7-9$ & Susceptible \\
\hline
\end{tabular}

\subsection{Disposal of Infected Plants and Planting Materials}

Infected plant samples in the experimental area have been collected and labeled; CSUT0, CSUT1, CSUT2, CSUT3, and CSUT4. Samples were brought to Chempro Analytical Services Laboratories, Inc. at 146 Shaw Blvd. cor San Roque St., Kapitolyo, Pasig City for silica content analysis using Lithium Borate Fusion/XRF. Planting materials such as pails and soil were subjected to solar heat treatment to reduce the number of existing bacteria introduced during the study.

\section{Statistical Tool}

The data obtained from this experiment were subjected to the Statistical Tools for Agriculture Research (STAR) or Microsoft excel using the analysis of variance (ANOVA) with a 5\% and 1\% level of significance. This means that making the correct decision in the research is $95 \%$ and $99 \%$ whether there are significant differences between treatments. The least significant at $5 \%$ (LSD $0.05 \%$ ) used to compare treatments. 


\section{Results and Discussion}

\subsection{Silica Analysis}

Results of the analysis revealed that the Rice Hull Ash (RHA) was composed of 87.34 wt. \% of SiO2 and the Soil that was collected from the Integrated Farm, Rice Field is composed of 68.49 wt. \% of SiO2. Production of silica can be achieved through an industrial-scale-based chemical, physical, mechanical, and thermal operation using a high degree of temperature with a large amount of acid $^{(12)}$. Studies show that RH and RHA consider as a significant source of high-quality silica that is being applied especially for enhancing the resistance of crops like rice ${ }^{(13)}$. As a byproduct through the process of combustion, RHA can generate energy. Some studies also use different treatments to obtain pure silica. Some techniques used for silica production are pre-treatment with alkaline and acid leaching. Fernandez conducted a comparison study on the purification and processing methods of Silica made by Rice Hull Ash (RHA). The result showed, using a simple way produced a high amount of Silica with a purity of $98 \mathrm{wt}$. \%. The present paper produced $87.34 \mathrm{wt}$. \% of $\mathrm{SiO} 2$ using a simple method; this corresponds to the study of $(7)$ using a combustion process that produced silica content of more than $85 \mathrm{wt}$. \%., on the composition of RHA. ${ }^{(14)}$, stated that the composition of Silica processed is mainly affected by the type of soil, weather, agronomic management, and other parameters.

\subsection{Plant Height (cm)}

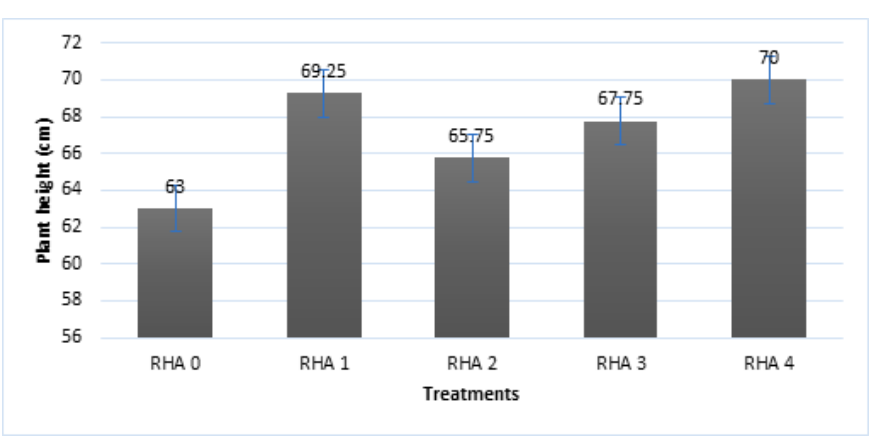

Fig 2. Mean height of plant per treatment as affected by RHA as a silicon source.

Figure 2 shows the mean length of the rice plants after the application of RHA as a rice resistance enhancer against Xanthomonas oryzae pv. oryzae, as gleaned in the table results show that there were significant differences in the plant height at a 95\% level of confidence between treatments. The control pot (treatment 0 ) has been recorded to have the smallest length with a mean of $63.00 \mathrm{~cm}$. Comparing among treatment means, RHA $4(70.00 \mathrm{~cm})$ as a reference value, when compared to the second-highest value, which is the treatment $1(69.25 \mathrm{~cm})$ have a difference of $0.75 \mathrm{~cm}$ showing no significant between the two treatments, when RHA 4 compared to RHA 0, 2, and 3 the LS differences were $7 \mathrm{~cm}, 4.25 \mathrm{~cm}$, and $2.25 \mathrm{~cm}$, respectively, which shows significance result among RHA treatments. Plant Height revealed that the application of RHA gives a significant effect on the development of rice, as highlighted by ${ }^{(15)}$, one morphological characteristic of hybrid rice has erect leaves, this also supported by the statement of ${ }^{(16)}$, that the rice plant's degree of erectness was based on differences and it can significantly be altered by nitrogen nutrition and silica, when there is a tendency to apply nitrogen, rice leaves become drooping, while silica makes the leaves more erect. Since rice is known to be as a Si- accumulator, its alleviated water stress, salinity stress, and nutrient deficiency or toxicity and improve erectness of the leaves ${ }^{(17)}$. The application of silicon to rice could also contribute vigor and boost rice yield and mitigate abiotic stress ${ }^{(18)}$. It also added that silicon improves the canopy photosynthesis of the leaves; thus, it improves light interception by keeping the leaves erect. Moreover, the application of Si enhances the development of a different variety of crops, which include wheat, barley, cucumber, and rice ${ }^{(19)}$.

\subsection{Bacterial Leaf Blight Severity of Infection}

The figure shows the mean, standard evaluation of bacterial leaf blight on the second day after inoculation. Results revealed a significant result in the resistance of bacterial leaf blight at a 95\% level of confidence between treatments. RHA 0 was recorded to have the highest infection rate index with a mean of 6.25, and this was followed by RHA 1, RHA 2, RHA 3, and RHA 4 with a severity mean index of 3.5, 3, 2.5, and 2.5 respectively. Comparison among treatment means wherein RHA 0 as the reference value, having a severity infection of 6.25 when compared to RHA 1, 2, 3, and 4 result shows that there were LS difference of 


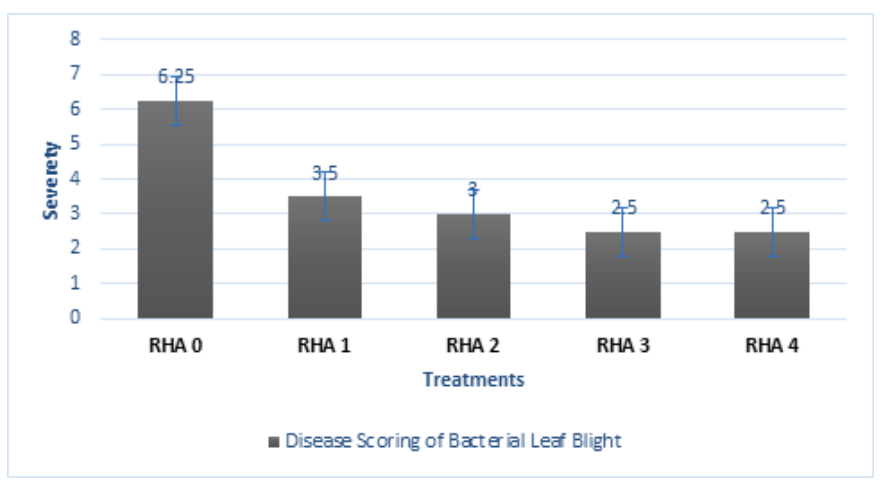

Fig 3. Mean severity of infection of Bacterial leaf blight as affected by RHA as a silicon source.

$1.75,2.25,2.75$, and 2.75 , respectively, which shows that all treatments used were significantly differenced with each other. Moreover, in terms of the disease reaction to Xanthomonas oryzae pv. oryzae, RHA 0 shows susceptible response because there was no intervention applied, RHA 1 shows Moderate response while RHA 2, 3, and 4 were all resistant to Xanthomonas oryzae pv. oryzae, Table 5 shows the Silica analysis report for the accumulation of rice conducted at Chempro Analytical Services Laboratory Inc., which RHA 4 (394ppm) and RHA 3(129.82ppm) obtained the highest silica accumulation, which supports the findings of the study. Severity revealed that silicon supplementation gives a significant effect against bacterial leaf blight attacks. The seriousness or incidence tends was reduced with increasing tissue contents of $\mathrm{Si}$ in rice ${ }^{(20)}$. The results support the study of $\mathrm{Han}^{(21)}$, that silicon amendment can influence biotic stress, where silicon is primarily deposited in the leaf's heath epidermal layer and creates a more efficient physical barrier to potential pests and diseases. The primary line for defense mechanism present in plants is on the surface. Most characteristics and functions of the plant surface become barriers for the penetration of the pathogen. However, $\mathrm{Si}$ is not sufficient to explain the mechanism of protection and this theory was maintained over the years ${ }^{(22)}$. Bloodnick ${ }^{(23)}$ stated that silicon has been shown to enhance drought tolerance, and retards premature defoliation of some crops that are not irrigated, and improved the resilience of plants toxicities micro-nutrients and other metals such as $\mathrm{Al}, \mathrm{Cu}, \mathrm{Fe}, \mathrm{Mn}$, and $\mathrm{Zn}$. Also it found that silicon helps to increase the strength of the stem. He also added that it demonstrated to increase the resistance to specific pathogenic fungi attacks such as powdery mildew and phytophthora. Datnoff ${ }^{(24)}$ added that silicon is deposited by silicon to form a skin-silicon double layer. This layer mechanically prevents penetration by microorganisms and interrupts the process of infection. Rice is known as silicon accumulator, and the plant is benefited from silicon nutrition. Thus, the accumulation of $\mathrm{Si}$ in the epidermal walls increases resistance against bacterial attack ${ }^{(20)}$. Research shows that there are benefits of silicon in some crops, mostly if grown on low quality land. However, there are only studies limited indicating that there may be benefits in greenhouse crops ${ }^{(6)}$ These beneficial effects when silicon was in the form of mono silicic acid. ${ }^{(25)}$, silicic acid is taken up in the root's hairs to the xylem vessel of the rice plant and distributed by the xylem vessel via transporters, also in the form of mono silicic acid. In the accumulation of silica in the shoots and leaves, mono silicic acid is polymerized into silica and deposited in the bulliform cells and under the cuticle. It was noted that when the rice has a low silicon uptake, it was proved to increase its susceptibility to some diseases such as brown spot, stem rot, grain discoloration, leaf blight, and rice blast $^{(23)}$.

Table 4. Disease index and the reaction of rice to the disease.

\begin{tabular}{ll}
\hline Treatment & Reaction \\
\hline RHA 0 & Susceptible \\
RHA 1 & Moderate \\
RHA 2 & Resistant \\
RHA 3 & Resistant \\
RHA 4 & Resistant \\
\hline
\end{tabular}


Table 5. Silica analysis report for the accumulation ofrice.

\begin{tabular}{ll}
\hline Treatment & Silica Accumulation; ppm \\
\hline CSUT 0 & $\mathrm{ND}^{\star} ; \mathrm{DL}^{\star \star}=0.02$ \\
CSUT 1 & 46.74 \\
CSUT 2 & 89.69 \\
CSUT 3 & 129.82 \\
CSUT 4 & 394.31 \\
\hline Legend: ${ }^{\star} \mathrm{ND}=$ None Detected ${ }^{* \star} \mathrm{DL}=$ Detec-
\end{tabular}

tion Limit

\section{Conclusion}

The result shows that RHA (Rice Hull Ash) as a Silicon source is a valuable supplement to improve rice resistance to BLB disease and as a substitute for chemical pesticides. Plant's evaluation of the plant disease is as high as $60 \%$ when compared to the highest infection rate to the lowest infection rate. In terms of plant height, CSUT 4 and CSUT 3 have shown significant results when compared to other treatments. However, in terms of financial wise to be used in field Basal Application, 15 DAT, and 30 DAT; 30 grams RHA is highly recommended. The study limits its scope on the vegetation stage of the rice; thus, it is recommended to continue until harvest to determine the full efficacy of RHA against biotic and abiotic stresses.

\section{Acknowledgement}

The authors would like to extend their heartfelt gratitude for those people who had become an integral part of making the research possible. Their organic department, the College of Agriculture, Cagayan State University-Piat Campus, to their Campus Executive officer Dr. Vicente S. Binasoy for his unending support.

\section{References}

1) Ainsworth EA. Rice production in a changing climate: a meta-analysis of responses to elevated carbon dioxide and elevated ozone concentration. Global Change Biology. 2008;14(7):1642-1650. doi:10.1111/j.1365-2486.2008.01594.x.

2) Han Y, Li P, Gong S, Yang L, Wen L, Hou M. Defense Responses in Rice Induced by Silicon Amendment against Infestation by the Leaf Folder Cnaphalocrocis medinalis. PLOS ONE. 2016;11(4):e0153918. Available from: https://dx.doi.org/10.1371/journal.pone.0153918.

3) Jawahar S, Jain N, Kumar SRV, Kalaiyarasan C, Arivukkarasu K, Ramesh S. Effect of silicon sources on silicon uptake and blast incidence in low land rice. Journal of Pharmacognosy and Phytochemistry. 2019;8(3):2275-2278.

4) Song A, Xue G, Cui P, Fan F, Liu H, Yin C, et al. The role of silicon in enhancing resistance to bacterial blight of hydroponic- and soil-cultured rice. Scientific Reports. 2016;6(1). Available from: https://dx.doi.org/10.1038/srep24640.

5) Todkar BS, Deorukhkar OA, Deshmukh SM. Extraction of Silica from Rice Husk. International Journal of Engineering Research and Development. 2016;12(3):1-1.

6) Onojah A, Amah A. Comparative studies of silicon from rice husk ash and natural quartz. American Journal of Scientific and Industrial Research. 2012;3(3):146-149. Available from: https://dx.doi.org/10.5251/ajsir.2012.3.3.146.149.

7) Cavins T, Marek S, Kamenidou S. Silicon stimulates photosynthesis, reduces transpiration rates and enhances plants' resistance to stresses. Features - Disease Control. . Greenhouse Management. 2010. Available from: https://www.greenhousemag.com/article/gmpro-1210-silicon-enhances-diseasesuppression.

8) Janislampi KW. Effect of Silicon on Plant Growth and Drought Stress Tolerance. 2012. Available from: https://digitalcommons.usu.edu/etd/1360/.

9) Kumar S. Plant Pathogens and Principles of Plant Pathology India. 2016. Available from: https://www.cabdirect.org/cabdirect/abstract/20173080716.

10) Wang M, Gao L, Dong S, Sun Y, Shen Q, Guo S. Role of Silicon on Plant-Pathogen Interactions. Frontiers in Plant Science. 2017;8. Available from: https://dx.doi.org/10.3389/fpls.2017.00701.

11) Cothran RD, Brown JM, Relyea RA. Proximity to agriculture is correlated with pesticide tolerance: evidence for the evolution of amphibian resistance to modern pesticides. Evolutionary Applications. 2013;6(5):832-841. Available from: https://dx.doi.org/10.1111/eva.12069.

12) Fernandes IJ, Calheiro D, Sánchez FAL, Camacho ALD, de Campos Rocha TLA, Moraes CAM, et al. Characterization of Silica Produced from Rice Husk Ash: Comparison of Purification and Processing Methods. Materials Research. 2017;20(suppl 2):512-518. Available from: https://dx.doi.org/10.1590/ 1980-5373-mr-2016-1043.

13) Hossain SS, Mathur L, Roy PK. Rice husk/rice husk ash as an alternative source of silica in ceramics: A review. Journal of Asian Ceramic Societies. 2018;6(4):299-313. Available from: https://dx.doi.org/10.1080/21870764.2018.1539210.

14) International Rice Research Institute. Standard Evaluation System (SES) for Rice. 5th ed.. 2013. Available from: http://www.clrri.org/ver2/uploads/SES_ 5th_edition.pdf.

15) Alvarez J, Lopez G, Amutio M, Bilbao J, Olazar M. Bio-oil production from rice husk fast pyrolysis in a conical spouted bed reactor. Fuel. 2014;128:162-169. Available from: https://dx.doi.org/10.1016/j.fuel.2014.02.074.

16) Haus R, Prinz S, Priess C. Assessment of High Purity Quartz Resources. In: J G, R M, editors. Springer Geology. Springer Berlin Heidelberg. 2012;p. 29-51. 
17) Ugheoke BI, Mamat O, Ari-Wahjoe B. A Direct Comparison of Processing Methods of High Purity Rice Husk Silica. Asian Journal of Scientific Research. 2013;6(3):573-580. Available from: https://dx.doi.org/10.3923/ajsr.2013.573.580.

18) Massey FP, Hartley SE. Experimental demonstration of the antiherbivore effects of silica in grasses: impacts on foliage digestibility and vole growth rates. Proceedings of the Royal Society B: Biological Sciences. 2006;273(1599):2299-2304. Available from: https://dx.doi.org/10.1098/rspb.2006.3586.

19) Daniells E, C S, Sullivan M. Pest Datasheet for Xanthomonas oryzae pv. 2011. doi:download.ceris.purdue.edu/file/3055.

20) Yoshida S, Navasero SA, Ramirez EA. Effects of silica and nitrogen supply on some leaf characters of the rice plant. Plant and Soil. 1969;31:48-56. Available from: https://dx.doi.org/10.1007/bf01373025. doi:10.1007/bf01373025.

21) Cuong TX, Ullah H, Datta A, Hanh TC. Effects of Silicon-Based Fertilizer on Growth, Yield and Nutrient Uptake of Rice in Tropical Zone of Vietnam. Rice Science. 2017;24(5):283-290. Available from: https://dx.doi.org/10.1016/j.rsci.2017.06.002.

22) Massey FP, Hartley SE. Experimental demonstration of the antiherbivore effects of silica in grasses: impacts on foliage digestibility and vole growth rates. Proceedings of the Royal Society B: Biological Sciences. 2006;273(1599):2299-2304. Available from: https://dx.doi.org/10.1098/rspb.2006.3586.

23) Bloodnick E. Role of Silicon in Plant Culture | PRO-MIX Greenhouse Growing. 2018. Available from: Https://Www.Pthorticulture.Com/En/TrainingCenter/Role-of-Silicon-in-Plant-Culture.

24) Datnoff LE, Rodrigues FA. The Role of Silicon in Suppressing Rice Diseases. APSnet Feature. 2005. Available from: www.apsnet.org/edcenter/ apsnetfeatures/Documents/2005/SiliconRiceDiseases.pdf.

25) Ma JF, Takahashi E. Soil fertilizer and plant silicon research in Japan. Amsterdam. Elsevier Sciences. 2002. 